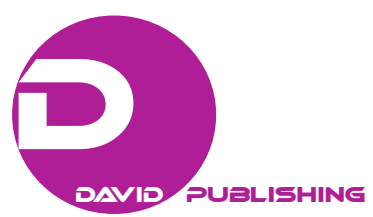

\title{
Rhodes's Men: Class, Race, and Ethnicity in International Leadership
}

\author{
Dana Cooper \\ Stephen F. Austin State University, Nacogdoches, Texas, USA
}

\begin{abstract}
At his death in 1902, Cecil Rhodes left an enormous amount of money to his alma mater, Oxford University to fund arguably the most recognized and prestigious scholarship in the world, the Rhodes Scholarship. Formally established one year after his passing, the grant quickly became the most famous educational award in the English-speaking world. Every year, 32 American college seniors are selected to study at Oxford University. ${ }^{1}$ Many of these elite men have returned from England to distinguish themselves in their chosen fields. Indeed the list of recipients reads like a Who's Who of American Leadership. Politicians such as senators J. William Fulbright and Bill Bradley, former President Bill Clinton, public policy analysts Robert Reich and George Stephanopoulos, writer Robert Penn Warren, as well as Supreme Court Justices Bryon White and David Souter, to name but a few, all achieved the status of Rhodes Scholars, a designation that has followed them thorough their respective and impressive careers (Schaeper \& Schaeper, 1998). Undoubtedly, this scholarship has had an enormous impact on the individuals who have been deemed worthy of its selection. Today, selection as a Rhodes Scholar is widely considered a golden ticket to future success for its recipients.
\end{abstract}

Keywords: Rhodes Scholarships, Manhood, Roosevelt, Leadership

\section{Introduction}

Upon a closer analysis of the Rhodes Scholarships, the specific requirements set forth by Cecil Rhodes and implemented by the Rhodes Trust reflect dominant themes of 19th and 20th century definitions of masculinity and the alleged inherent connection with national and international leadership. Rhodes was, for better or for worse, a product of his time, class, and circumstance. As Nancy Cott and Drew Gilpin Faust (2005) argued over a decade ago, "every historical actor is shaped and influenced by gender attributes and by the existence of gender categories in social organization and in structures of representation" (p. 4). Rhodes was no exception to this historical rule. As a elite Anglo-Saxon man living in the age of the British empire, his life, and particularly his legacy, in regards to the Rhodes Scholarship, provides an excellent opportunity to analyze the notion that "the ever shifting meanings of 'gender' and of 'race' rest in historical experiences and circumstances". 2

Dana Cooper, Associate Professor, Department of History, Stephen F. Austin State University.

1 John McCall MacBain, an advertising tycoon from Canada, expanded the reach of the Rhodes Scholarships significantly in 2013 when he gave $£ 75$ million (approximately USD \$126 million) to the Rhodes Scholarship Trust, which was structured to foster matching gifts to expand the scholarships to include Russia, Brazil, Japan, and China; thus, the Rhodes Scholarships may well be very different in reality in the 21 st century than Rhodes's original intent in the 20th century. "Rhodes and Oxford: Giving it up for Cecil", The Economist, September 21, 2013.

${ }^{2}$ Ibid. 
Following Rhodes's stipulations as presented in his final will, the Rhodes Selection committee annually evaluates potential scholars in four main areas: scholarly excellence (3/10), manly outdoor sports (2/10), qualities of "manhood" (3/10), and their potential as men of influence who are dedicated to service to the public duty for a higher aim (2/10) (Schaeper \& Schaeper, 1998, p, 17). In Rhodes's mind, the best leaders with future careers in international politics were high-achieving and well-rounded men who both excelled in the classroom and expressed an interest in public service. "By public duty Rhodes did not mean purely political life. He understood public duty in a characteristically late Victorian manner", notes Julian Ogilvie Thompson, a Rhodes Trustee, "explained as involving a commitment, in whatever career a Scholar pursued, to the civic virtue. His Scholars were not to be chosen from those committed merely to their own individual self advancement".

Originally termed the dream of Cecil Rhodes, the idea of some sort of unofficial (in existence) but mostly official (in influence) grew into "Rhodes's secret society" (Quigley, 1981, p. 4). But by the time of his death, and several evolving wills later, Rhodes has settled on an international scholarship program to bring the English-speaking world together and transform nations through Anglo-Saxon leadership. Although aimed at elite, white, and affluent men, the unveiling and discussion of the scholarships contained notable stipulations. Significantly, Rhodes specifically required that no applicant would be disqualified for a scholarship on account of his race or religious belief (Rhodes, 1902). Thus, even in the non-secular world of the 19th-and early 20th-century, one's ethnicity and religious affiliation were less important in Rhodes's estimation than sex in measuring the capabilities of one's potential for international leadership. ${ }^{5}$ As a result, women could not apply for the scholarships until 1976 (Schaeper \& Schaeper, 1998, p. 248).

Rhodes originally established his international scholarship program at the beginning of the 20th century to nurture closer relations between the English-speaking nations but reactions were mixed depending on the side of the Atlantic on which one found oneself (Rhodes, 2014, p. 9). Overall, the British response to Rhodes's will was positive, contended that it should be "welcomed by all who love their country and desire the advancement of the British name". 6 The will was hailed as "the most remarkable testament that was ever signed". 7 Many Britons lauded Rhodes's "magnificent bequest to his old University", and surmised that "[I]t will startle Americans to find an Englishman endowing their young men". ${ }^{8}$ But some Americans did not respond well to such a program and felt that "America has no need of testamentary bequests". In his letter to the editor of The New York Times, Stephen R. Tobin maintained that American "men have better facilities for education and mental development in the numerous colleges and universities scattered all over the land than are afforded by

\footnotetext{
${ }^{3}$ Such a stipulation begs the question, as posed by historian Philip Ziegler, whether Rhodes Scholars perform public duties because they are Rhodes Scholars or whether they are selected for such a distinction because they are likely to perform public duties (Ziegler, 2008, p. 333).

4 "To 'render war impossible': the Rhodes Scholarships, educational relations between countries, and peace" , a speech by the Warder of Rhodes House, Oxford, Dr Donald Markwell at the 'Sailing Dinner' of the Canadian Association of Rhodes Scholars, Ottawa, Saturday, September 24, 2011, 4. Retrieved December 1, 2015, from http://files.www.rhodesscholarshiptrust.com/

5 While Rhodes's will stated that neither race nor religion should be an issue in selecting Rhodes Scholars, some historians have argued that Rhodes never envisioned this clause including individuals of African descent. Cecil Rhodes, "The last will and testament of Cecil John Rhodes: with elucidatory notes to which are added some chapters describing the political and religious ideas of the testator," edited by W.T. Stead. The Bodleian Library, Oxford, 1902, 9. Thus, the selection of African-Americans or women as Rhodes Scholars, such as Gretchen Rohr, who proudly accepted the award even as she openly questioned race relations in the United States and criticized Cecil Rhodes limited perspective, would likely have shocked the educational benefactor (Rohr, 1999).

6 Mr. Rhodes's will. The Daily News (London), April 5, 1902.

7 Ibid.

8 Mr. Rhodes's Bequest to Oxford. The Daily News, April 7, 1902. London.
} 
the cloisters of ancient Oxford". Tobin suggested that Rhodes's will be rejected and all funds invested in South Africa to assist destitute families in the case of "patriotism and Christian charity". ${ }^{9}$ His suggestions were not implemented.

Regardless of the controversial nature of Rhodes's will and his intentions, one area not criticized, and one at the center of this study, is an examination of the application qualifications as identified by Rhodes and their assumed relationship to conceptions of masculinity at the turn of the 20th century. Upon close analysis, these requirements reveal the founder's ideals regarding what he deemed the interrelated themes of empire, race, education, masculinity, and international leadership. Through his Rhodes Scholarships, the nature and personality of international leadership was largely influenced, shaped, and dictated by a masculinized conception of who should serve as international leaders and overtly outlined the masculine characteristics worthy individuals had to possess in order to become one of the elite Rhodes Scholars, and thus, one of "Rhodes's Men". ${ }^{10}$

\section{A Brief History of the Rhodes Scholarships}

In 1873, Cecil Rhodes applied for admission to Oxford University (Rotberg, 1988, pp. 85-86). Having spent the last two years establishing himself as a business entrepreneur in South Africa, he had shown an interest in political office. His personality, however, required the respect from his peers that only an Oxford education could provide. Between 1873 and 1881, Rhodes divided his time between supervising his diamond mines in Kimberly, a precursor to his creation of the De Beers Consolidated Diamond Mining Company, and nine academic semesters at Oxford. He took a pass degree from Oriel College after eight years of study, a degree that normally took three (Rotberg, 2014).

Halfway through his intermittent studies at Oxford, Rhodes suffered a heart attack in 1877. Following this significant health episode, he drafted his first will in which he expressed his earnest hope for the Anglo-Saxon race to rule the world through a united empire. As he regained his health, he accumulated power and wealth in South Africa as an increasingly successful businessman. At the same time, his subsequent wills express his desire for the United Kingdom and United States, which evolved from proposing a secret society to establishing a renowned educational program. The creation of the Rhodes Scholarships provided Rhodes a permanent connection to his alma mater but also the opportunity to define masculinity on an international level even as his fortune funded imperial dreams in an effort to secure his legacy.

In establishing the Rhodes Scholarships, the founder hoped to provide his scholars with the opportunity to develop an international perspective. By exposing his scholars to a kinship among the English-speaking nations of the world, Rhodes hoped that these young gentlemen would discover similarities among their cultures while studying and creating something of an international fraternity in what one biographer has termed the "mystic vortex of Oxford" (Flint, 1974, p. 238). According to historian Bradford Perkins (1968), "[A]s a young man, Rhodes dreamed of political reunification, and he always considered the American Revolution a tragic, stupid accident which set back the race's domination of the world" (pp. 80-81). According to Frank Aydelotte (1946), a historian of the Rhodes Scholarships, "[T] he reunion of the mother country with the lost American colonies

\footnotetext{
9 The Legacy of Cecil Rhodes. The New York Times, April 13, 1902.

${ }^{10}$ My ongoing research evaluates the original goal of the Rhodes Scholarships and its efforts to ameliorate Anglo-American relations; thus, this work focuses on conceptions of masculinity in the United States and Great Britain at the turn of the 20th century. This study does not attempt to examine the other "white" colonies or dominions included in the Rhodes Scholarships.
} 
was one of the most definite objects of his life. He cherished the idea of this reunion upon any terms by which it could be accomplished" (p. vi).

Rhodes anticipated that in their time at Oxford, his scholars would discover the shared Englishness between their civilizations. Rhodes believed that their common language and shared law were significant, but that many intangibles united the Anglo-Saxon race. Rhodes wished for his scholars to come to realize that a sense of unity among the Anglo-Saxon nations could act as a foundation for Britons and Americans in easing international relations at a critical point in their shared history. Though some may contend that Rhodes "always dreamed of the union of South Africa", far more people spoke of Rhodes's hope "that the English race was called to rule over the whole earth". ${ }^{11}$ Known far and wide for his desire "to weld the Empire by secret bonds, of political intrigue and propaganda", Rhodes undoubtedly believed in the superiority of the Anglo-American race, the supremacy English-speaking people, and an adamant belief that the human race would benefit from world domination by Anglo-Saxons (Roberts, 1988, p. 37). ${ }^{12}$ But his global vision rested on a shared educational experience serving as the catalyst that would foster bonds between these people. Rhodes was certain that such an approach would "render war impossible" by promoting peace through the creation of goodwill between future leaders around the world based on their mutual experiences as students at his alma mater. ${ }^{13}$ In describing "the nobility of his intentions", historian Philip Ziegler insists that Rhodes wanted nothing less than for "his Scholars to transform the world" (Ziegler, 2008, p. 19). As early as 1877, Cecil articulated his views regarding his perceived superiority of the Anglo-Saxon race in his Confession of Faith. Still a student at Oxford at 24 years old, and without reservation, he considered the English "the finest race in the world" and maintained that the world would benefit if more English people and values expanded across the globe through the means of "imperial conquest and imperial values" (Rotberg, 2014, p. 558). He unabashedly insisted that Anglo-Saxon character and influence would "end wars, [and] enrich peoples lives everywhere" (Rotberg, 2014, p. 555). As these thoughts solidified in his mind, Rhodes began arranging his finances to support an imperial plan through educational means (Verschoyle, 1900, p. 7).

In applying these ambitious intentions, Rhodes's initial efforts at building an Anglo-American amity may have rekindled in December 1890, when he attended an alumni dinner of male graduates of Grey College. He was deeply impressed by the enthusiasm of the graduates, their friendship for each other, and their devotion to their alma mater (Aydelotte, 1946, p. 10). Perhaps it was at this critical point that Rhodes made a connection in his mind as to his long-term goals for Britons and Americans through education.

An analysis of Rhodes's seven wills, written between 1877 and 1899, reveals the evolution of his ideas on culture, education, and international leadership. Although he had toyed the idea of a secret society modeled along the lines of the Jesuits or the Masons in various versions of his early wills, Rhodes later dropped the idea entirely and replaced it in his sixth and seventh wills in 1893 with a new idea that moved from "expanding the empire to acculturating its sons" (Rotberg, 2014, p. 562). While this concept centered on a residential university located in South Africa, Rhodes later dismissed it in his final will where he outlined his new vision for educating young American men at Oxford (Rotberg, 2014, p. 564). This newfound academic program would

\footnotetext{
11 The Dream of Cecil Rhodes. The Daily News (London), July 28, 1909; "The Funeral of Mr. Rhodes", The Daily News (London), April 9, 1902.

12 "Old Schools in New Lands", The Daily News (London), April 24, 1903.

13 "To 'render war impossible': The Rhodes Scholarships, educational relations between countries, and peace", a speech by the Warder of Rhodes House, Oxford, Dr. Donald Markwell at the 'Sailing Dinner' of the Canadian Association of Rhodes Scholars, Ottawa, Saturday, September 24, 2011, 5. Retrieved December 1, 2015, from http://files.www.rhodesscholarshiptrust.com/
} 
bring young men, American and Briton, together to establish relationships, and ideally politically advantageous friendships, hopefully for these same individuals taking national and international leadership positions at a later date (Aydelotte, 1946, pp. 6-19).

Rhodes desired that by selecting men of exceptional personal integrity and potential for leadership in the future, these gentlemen could meet and come to understand one another during the formative years of their lives. Exposure between the future leaders of the English-speaking nations, in Rhodes's vision, would all but guarantee a melding of the cultures and improved diplomatic relations in future generations. ${ }^{14}$

\section{Defining Scholarly Excellence for Men}

In his final will, written in July 1899, Rhodes expressed his specific wishes and prescription for assessment in awarding the scholarships.

My desire being that the students who shall be elected to the scholarships shall not be merely bookworms. I direct that in the election of a student to a Scholarship [sic] regard shall be had to (i) his literary and scholastic attainments; (ii) his fondness of and success in manly outdoor sports such as cricket, football, and the like; (iii) his qualities of manhood, truth, courage, devotion to duty, sympathy for and protection of the weak, kindliness, unselfishness, and fellowship; and (iv) his exhibition during school days of moral force of character and of instincts to lead and to take an interest in his schoolmates for those later attributes will be likely in afterlife to guide him to esteem the performance of public duties as his highest aim. (Rhodes, 1902, p. 11)

These foundational influences shaping Rhodes's ideas about scholarly excellence seem to have originated in his own experiences as a student at Oriel College. Students at Oxford and Cambridge, an institution Rhodes generally referred to as the "other" place, endured a similar process as they secured their respective degrees (Schaeper \& Schaeper, 1998, p. 16). The final step in earning a degree at these universities was a series of stressful and demanding competitive examinations, a critical step in gaining a position in government or civil service (Deslandes, 2002, p. 544). Called the Previous (or sometimes the Little-Go) at Cambridge and the Responsions at Oxford, these exams marked the transition from boyhood to manhood as the collective experience of Oxbridge men (Deslandes, 2002, pp. 549-554). Due to the consequence of these exams, they marked a significant milestone in a young man's career both for himself and the people who surrounded him at this critical juncture (Deslandes, 2002, p. 552).

Pertinent in analyzing such gendered ideas of scholarly excellence is the notable absence of women from examinations. In the late 19th century, women began to enter the universities such as Oxford and Cambridge as students but to a limited extent. Educational reforms over time allowed women to take exams but prevented them from receiving formal degrees until the 20th century (Deslandes, 2002, pp. 565-566). "As an experience endured in the company of other men, and removed from the presence of women, examinations, like other masculine rituals, served functions similar to those identified by anthropologists in non-industrial societies where, it has been observed, male friendships center on activities as opposed to specific moments of intimacy" (Deslandes, 2002, p. 559), a quality more typical in feminine friendships. Thus the preparation and toleration of the exams served as a process that bonded Oxbridge men together, a development that shaped gender identities and established a sense of masculine power, solidarity and influence (Deslandes, 2002, p. 559).

\footnotetext{
${ }^{14}$ Having much of the opposite effect that Cecil Rhodes originally hoped for, only $7 \%$ of Rhodes Scholars between 1904 and1950 entered government service. The greatest number of scholars in the same period were employed in education (40\%) followed by careers in law (20\%). Comparable numbers hold for a second period (1951-1997) of evaluation (Schaeper \& Schaeper, 1998, pp. 278-279).
} 
Nonetheless, exams for Oxbridge men held significant meaning for the women in their lives by serving as a means to exhibit masculinity and thus to please relatives and female admirers (Deslandes, 2002, p. 570). In this context, exams functioned as an "opportunity to display one's intellectual abilities and masculine prowess to potential financial dependents" (Deslandes, 2002, p. 570). Striving to please family and potential family relatives, Oxbridge men also dealt with the dilemma of satisfying or disappointing one's father. As male students expressed

Both respect and disdain for this central figure in his life who occupied, simultaneously, the role of stern disciplinarian and task-master, breadwinner, and paragon of masculinity... concerns about pleasing one's father represented an ultimate expression of the precariousness of the undergraduate's position as a man. His financial dependence, professional uncertainly, youth, and need for familial approval made him dread this man but also yearn deeply for his support. (Deslandes, 2002, p. 571)

Cleary, the centrality of family and women in the process of exams produced a great deal of anxiety for Oxbridge men.

Outside of the familial context, exams also presented a unique opportunity for community building among the men themselves (Deslandes, 2002, p. 558). The exam process served a vital role in the formation of masculine identities at the universities as the experience prepared undergraduates to act as "one great band of brothers" in the world (Deslandes, 2002, p. 558). By drawing on their mutual experiences, largely unique to Oxbridge men, they were able, both during and after graduation, to refer to that sense of commonality that was so integral to the perpetuation of elite, male status (Deslandes, 2002, p. 558). This opportunity for camaraderie as presented undergraduates with an opportunity for social bonding as well as a chance to celebrate their successes and mourn their failures in a collective fashion (Deslandes, 2002).

Finally, and perhaps most importantly, the importance of scholarly excellence as demonstrated through a performance in exams held significance for each individual Oxbridge man. "The end of the undergraduate academic career, punctuated as it was by final examinations, meant 'farewell' to a familiar way of life. As part of the maturation process, undergraduates were aware that the completion of exams and a degree signaled the arrival of their obligations... and responsibilities as adult men”. To perform successfully in competitive exams foreshadowed a successful future as a man; to fail as a student fated oneself as a failure as a man. Thus, "academic exercises, within this context, became gauges of professional masculinity which could measure the candidate's competitive spirit, endurance, stamina, strength, diligence, ability to overcome adversity and rise to any challenge, [and] gentlemanly proficiency" (Deslandes, 2002) as they proved their academic ability, which signified their success as leaders.

\section{The Importance of Athleticism and Sports in Masculinity}

Just as competitive examinations supplied Oxbridge men with "a chaotic opportunity for men to test their physical limits once again", sports and athleticism served as a critical factor in Rhodes's search for exceptional men academically and physically fit to conduct international relations (Deslandes, 2002, p. 559). Described as a process whereby "the puny youngster [was] converted into the muscular man", the competitive nature of examinations shared an inherent connection with the competitive nature of sports for both Oxbridge men and Rhodes Scholars (Deslandes, 2002, p. 559). Rhodes stipulated in his will that applicants hold a "fondness of and success in manly outdoor sports such as cricket, football and the like" (Schaeper \& Schaeper, 1998, p. 16). 
Rhodes's interest in manly vigor, sports, and energetic Anglo-Saxon leadership was something that he shared with several other world leaders of the era. The two most famous were German Kaiser Wilhelm II and US President Theodore Roosevelt. Wilhelm II had a deformed left arm. Many authorities have concluded that the Kaiser's zeal to compensate for this handicap contributed to his dismissal of Bismark, his drive to build up the Germany navy, and his imperialistic dreams. Like Rhodes, Roosevelt was considered to be a weak and sickly child. Both men suffered from asthma as children, and their respective families sent them away to more hospitable climates as to recuperate from their afflictions. ${ }^{15}$ Roosevelt's adventures as a cowboy, a Rough Rider, and an African hunter may have meant from him what South African cotton farming and diamond conquests signified for Rhodes. ${ }^{16}$

Roosevelt preached the cult of masculinity in several of his speeches and books, especially The Strenuous Life (DiNunzio, 1994, pp. 184-189). In an 1899 address in Chicago, shortly before Rhodes's and the unveiling of his scholarships, Roosevelt's rhetoric provide insight into his Victorian-based experiences, which shaped his upper-class concepts of appropriate American ideals regarding physical and moral manliness. He reflected:

I preach to you, then, my countrymen that our country calls not for the life of ease but for the life of strenuous endeavor. The 20th century looms before us big with the fate of many nations. If we stand idly by, if we seek merely swollen, slothful ease and ignoble peace, if we shrink from the hard contests where men must win at hazard of their lives and at the risk of all they hold dear, then the bolder and stronger peoples will pass us by, and will win for themselves the domination of the world. Let us therefore boldly face the life of strife, resolute to do our duty well and manfully; resolute to uphold righteousness by deed and by word; resolute to be both honest and brave to serve high ideals, yet to use practical methods. Above all, let us shrink from no strife, moral or physical, within or without the nation provided we are certain that the strife is justified, for it is only through strife, through hard and dangerous endeavor, that we shall ultimately win the goal of true national greatness. (DiNunzio, 1994, p. 189)

Thus, for Rhodes, Roosevelt, and many other Anglo-Saxon men in the age of imperialism, physical superiority as exhibited through manly sports acted as a reflection of society. "Various communities of men in the British Empire", Patrick McDevitt (2004) argues, "used sport to construct, propagate, and maintain national conceptions of manhood" (pp. 2-3). Much like competitive exams, Britons increasingly viewed manly sports as means by which physical activity vigorously created men out of boys (Putney, 2001). As such, manly sports included cricket and football while tennis and golf were considered "safe" sports as they did not threaten women's reproductive capabilities. Once again, the absence of women in specified sports determined the masculinity of the activity (Burstyn, 2000; Hooper, 2001; McKay, Messner, \& Sabo, 2000). Based on Roosevelt's own writings and Rhodes's will, the connection between victory in the athletic arena and conquest in the political arena is clearly illustrated. In his examination of Roosevelt's virility, historian Arnaldo Testi described this intellectual and physical intersection as the president "playing the masculine hero of muscle and mind" (Testi, 1995). At the turn of the 20th-century, ideas equating masculine physical superiority with political success were shared on both sides of the Atlantic.

\footnotetext{
15 While able to transform himself from a ailing boy into a physically robust man, Roosevelt suffered from asthma throughout his life (Cadenhead, 1974, p. 4).

${ }^{16}$ Roosevelt never forgot him time and transformation in the West, and the experience always provided him a level of authority and legitimacy in speaking of "manhood" and "masculinity" in a way that many of his later political compatriots did not possess (Cadenhead, 1974, pp. 27-28).
} 


\section{Identifying Qualities of "Manhood"}

Even as Rhodes sought an interest in assertive men suitable for political positions, he also expressed his desire to seek true gentlemen. In his will, he discussed the "qualities of manhood, truth, courage, devotion to duty, sympathy for and protection of the weak, kindliness, unselfishness, and fellowship" (Schaeper \& Schaeper, 1998, p. 16). Even as the Rhodes Scholars had to be exceptional men in the classroom and in the sporting arena, they also had to be gentlemen in the truest sense of the word. Rhodes intended for the selection committee to use its own judgment and intuition in recognizing candidates who had a special spark of character and potential greatness. Of all of the categories in the scholarship, this category is perhaps the most subjective and thus, the most difficult evaluate through an application or interview and even for scholarly research.

Based on his wills and writings left behind, Rhodes said the least about his definitions and qualifications for manhood. However, scholars can assume with a degree of certainty what Rhodes was referring to a specified code of personal behavior and one that united strength of stature as well as strength of character. While this particularly category of assessment seems the most obvious, it is also the most elusive. Clearly, it was important to Rhodes that his scholars be exceptional men in the classroom and in an athletic context, a person who would take advantage of another's disadvantages or exhibit arrogance because of their success was not a gentleman in Rhodes's mind. First and foremost, in his search for men to lead the nation and world was an individual who looked out for the needs and interests of others.

In an American context, Roosevelt voiced these same ideals. In his 1900 publication, he stated that, "[W]e admire the man who embodies victorious effort; the man who never wrongs his neighbor; who is prompt to help a friend... [A]bove all, let us shrink from no strife, moral or physical, within or without the nation, provided we are certain the strife is justified..." (Merrill \& Paterson, 1899, pp. 459, 461). Yet Roosevelt demanded much of men, specifically American men. In a speech to the Groton School for Boys in 1904, he declared that Americans had "a right to expect of the American boy that he shall turn out to be a good American man... He must not be a coward to a weakling, a bully, a shirk, or a prig. He must work hard and play hard. He must be clean-minded and clean-lived, and must be able to hold his own under all circumstances and against all comers" (Watts, 2003, p. 46). Roosevelt believed fully in the need to protect the weak, service to the country regardless of potential cost, and a strong sense of duty in living for others (Hardy, 2015). In this sense, Roosevelt and Rhodes shared a transatlantic concept of manhood. Physical and mental toughness prepared men for the future. ${ }^{17}$ However, while Rhodes and Roosevelt sought a competitive spirit intellectually and athletically, they agreed that the very same spirit had to temper such assertiveness in achieving the title of gentleman.

\section{Moral Men, Dutiful Men}

The final area of judgment for Rhodes Scholars is closely related to the previous notions regarding gentlemanliness and manhood. In his own words, Rhodes required that his scholars must have exhibited "during school days [a] moral force of character and of instincts to lead and to take an interest in his schoolmates for those later attributes will be likely in afterlife to guide him to esteem the performance of public duties as his highest aim”. Relying on an interest taken in others would translate into an interest in serving

\footnotetext{
17 Roosevelt often discussed his transformation into a "manly man" and commented on its necessity for "The Vigor of Life" (Roosevelt, 1913, pp. 32-60).
} 
others at a later date, Rhodes continued his prescription of a particular concept of masculinity which focused on service to others and leading a nation. Rhodes's ideas of leadership for the British Empire can be equated to a sense of obligation in a military sense. For a man to shirk his duty in military service would be seen by society as a disgrace. Apparently, Rhodes felt a similar reaction in men shirking their leadership duties to king and country. A clear factor critical to Rhodes's conception of masculinity was national and international leadership. Without such service, men failed to earn the title of man.

Once again, Roosevelt echoes Rhodes's commitment and reverence for a man's duty in life. "The 'duty of life", according to biographer Sarah Watts (2003), "like the chief utility of sports, was to "encourage manliness and vigor, and to keep men hardy, so that at need they can show themselves fit to take part in work or strife for their native land"' (p. 51). While racist and imperialist in perspective, Roosevelt viewed non-Anglo-Saxons as a burden that white men had to take on as part of their Christian duty (Dyer, 1980, pp. 45-68). He often spoke of the Spanish-American War in terms of an American duty as part of a man's duty to the state and the turning point when Americans decided whether to dominate the Western Hemisphere or be dominated (Dalton, 2002, p. 165). For Roosevelt, to falter in this manly, military duty placed an individual's manly status in jeopardy. Drawing upon his military background, he went so far as to conjure up the memory of Abraham Lincoln and the Civil War.

When you went into battle you were not thinking of your rights, you were thinking of your duties, of your duty to the flag, your duty to the country, your duty to the men and women you had left behind, who would rather that you gave that duty even at the cost of life than that you shirked your duty and saved your life. That is what you thought of, and if you had not thought of that you would not have been worth your salt as soldiers. If you had not put duty first and foremost we would not now have had a great united country... ${ }^{18}$

Very similar to one's performance in examinations, Roosevelt spoke of the potential pride or potential shame a man's family would experience dependent on a manly performance. For Roosevelt and Rhodes, a great deal of overlap existed between these prescribed qualities of transatlantic masculinity.

\section{Death and Legacy}

In reflecting on his life, and with his last words, Rhodes remarked, "[S]o little done; so much to do". 19 Upon his death in 1902, Rhodes was mourned and lauded around the world-from Great Britain to South Africa to the United States. News of his death, "the Napoleon of Africa", met with "profound grief" in Cape Town, and [A]ll places of amusement were immediately closed". ${ }^{20}$ In a special cablegram from London to The New York Times, celebrated writer Rudyard Kipling, whose own love story with Anglo-Saxonism included an American wife, wrote a poem titled The View of the World, that was read at Rhodes's funeral in Rhodesia. The elegy praised Rhodes as a "[D]reamer devout, by vision led, [B]eyond our guess or reach", and praised his efforts to link nations and envisage empires unimagined to date. ${ }^{21}$ In a similar vein expressed in his earlier work, "The White Man's Burden", Kipling continued to pay tribute to those men who dedicated their lives to empire building that promoted the Anglo-Saxon world.

\footnotetext{
18 Theodore Roosevelt, 26th President of the United States of America. Member of the History Channel Network. (CChapultepec, Inc., 1999-2005. Retrieved March 27, 2005, from http://www.theodore-roosevelt.com/trdutyandcontrol.html

19 Mr. Rhodes. The Daily News, March 28, 1902. London.

${ }^{20}$ Death of Cecil Rhodes. The New York Times, March 27, 1902.

${ }^{21}$ Kipling's Tribute to Cecil Rhodes. The New York Times, April 19, 1902.
} 
But despite the laudatory exit he received around the world in 1902, Rhodes's legacy a century later proves far more controversial. In early 2015, passionate debate about Rhodes, as both philanthropist and racist, gripped South Africa through much of the spring as a "historical amnesia" came to an end at the University of Cape Town. ${ }^{22}$ Students voiced their collective opinion of Rhodes when in March they threw human excrement on the statue of Rhodes at the University of Cape Town. ${ }^{23}$ One newspaper described the significant protest as "Rhodes rage", while others flocked to Twitter and posted various comments under the theme \#Rhodes Must Fall as some students demanded that the statue be removed from the university premises. ${ }^{24}$ Following a vote by the university council, and a month of student demonstrations, Rhodes's statue was removed in April from university grounds. But just days later, students found the shadow of Rhodes has been "painted on the ground, as if cast by the fallen monument". ${ }^{25}$ These events, tangentially related to the Rhodes Scholarships, and related acts of protest in South Africa opened a sensitive debate about "heritage, identity, and race". ${ }^{26}$

In response to the controversy, the Rhodes Trust acknowledged the "diversity of legitimate opinions on the issue", and noted that "Rhodes Scholars around the world will want to find their own way of thinking about and addressing these questions". Identifying the organization as a "future-focused organization", they were quick to note the purpose of the scholarship was to promote "education and leadership development", and wisely list the "substantial number of [Scholars] whom are occupied at the forefront of human rights work and are key advocates for expanded social justice". ${ }^{27}$

In conclusion, Cecil Rhodes left behind a complicated and twisted legacy for scholars to consider. Many in South Africa see him as a "notoriously racist mining magnate". ${ }^{28}$ Britons may well summarize their thoughts on Rhodes with a brief attribution for his central role, or speculation thereof, in the 1895 Jameson Raid. ${ }^{29}$ A documentary of the businessman, directed by a Briton, observed that its portrayal of Rhodes was "stinging with British irony, etched in acid". In the end, the director dismissed Rhodes, and his enduring scholarship legacy as little more than "an Anglo-Saxon union at Oxford University for teutonizing the world" (O'Connor, 1981). In many cases, Americans simply want to take advantage of the Rhodes Scholarship opportunity without a close examination of what the financier, much less his means or methods, provided the funded for such an opportunity.

But more than a simple review of Cecil Rhodes, the individual, a close analysis of the Rhodes Scholarships provide current scholars an opportunity to analyze the concept of masculinity as it was defined by contemporary societal ideas at the late 19th and early 20th centuries. An examination of the program reveals that the nature and personality of such international leadership was influenced, shaped, and dictated by a

\footnotetext{
22 South Africa's Odious Monument to Cecil John Rhodes. The New York Times, March 26, 2015.

23 Students in South Africa Protest Slow Pace of Change. The New York Times, September 8, 2015.

${ }^{24}$ Ibid; Why is Cecil Rhodes such a controversial figure? BBC News, April 1, 2015.

25 Students in South Africa Protest Slow Pace of Change. The New York Times. September 8, 2015.

${ }^{26}$ Students' Attack on Cecil Rhodes Statue Leads to Soul Searching in South Africa. The Guardian, March 20, 2015. Retrieved November 5, 2015, from http://www.theguardian.com/; White blacklash as colonial statue comes down in South Africa. The Telegraph, April 9, 2015. Retrieved October 27, 2015, from http://www.telegraph.co.uk

27 Cecil Rhodes \& His Legacy. The Rhodes Scholarships. Retrieved November 30, 2015, from http://www.rhodeshouse.oc.ac.uk/rhodesandlegacy

${ }_{28}$ White blacklash as colonial statue comes down in South Africa. The Telegraph, April 9, 2015. Retrieved October 27, 2015, from http://www.telegraph.co.uk

${ }_{29}$ The Methods of Cecil Rhodes. The New York Times, April 27, 1902. Death of Mr. Cecil Rhodes. The Guardian, March 27, 1902. Speculation had long cast aspersions on Rhodes as a co-conspirator with Leander Starr Jameson in an attempt to overthrow the Boer government in 1895-1896.
} 
masculinized conception of who should serve as international leaders and the masculine characteristics such men had to possess in order to even be considered for such leadership. Young men were expected to excel in the classroom and on the sporting field. Yet they also had to control their ambitious drive so as not to harm or take advantage of their fellow man. Assertiveness and confidence had to be tempered with kindness and compassion in order to be considered a gentleman. Finally, men were expected to fulfill their manly duty in service to his country most if at all possible through national or international political service. Certainly achieving all the expectations set by society, family, friends, and even oneself was a daunting task in this period. Arguably, it was hard to be a "man" at this time in history with all that such a label entailed. Clearly, elitism and exclusion were key factors of masculinity at the turn of the century. This fact is reflected in the quest of young men (and after 1976, young women) to become one of the elite Rhodes Scholars, and thus, one of "Rhodes's Men".

\section{References}

Aydelotte, F. (1946). The American Rhodes Scholarships: A review of the first forty years. Princeton, New Jersey: Princeton University Press.

Burstyn, V. (2000). The Rites of men: Manhood, politics, and the culture of Sport. Toronto, Canada: University of Toronto Press.

Cadenhead, Jr., I. E. (1974). Theodore Roosevelt: The paradox of progressivism. Woodbury: New York: Barron's Educational Series, Inc.

Cott, N. F., \& Faust, D. G. (2005). Foreword: Recent directions in gender and women's history. OAH Magazine of History, 19(2), 4-5.

Dalton, K. (2002). Theodore Roosevelt: A strenuous life. New York: Alfred A. Knopf.

Deslandes, P. R. (2002). Competitive examinations and the culture of masculinity in Oxbridge undergraduate life, 1850-1920. History of Education Quarterly, 42, 545-578.

DiNunzio, M. R. (Ed.). (1994). Theodore Roosevelt, an American mind: A selection from his writings. New York: St. Martin's Press, Dyer, T. G. (1980). Theodore Roosevelt and the idea of race. Baton Rouge: Louisiana State University Press.

Flint, J. (1974). Cecil Rhodes. Boston: Little, Brown and Company.

Hardy, R. (2015). Theodore Roosevelt and the masculine/feminine complex. Retrieved October 27, 2015, from http://cat.middlebury.edu/ nereview/26-4/Hardy.html

Hooper, C. (2001). Manly states: Masculinities, international relations, and gender politics. New York: Columbia University Press.

Marlowe, J. (1972). Cecil Rhodes: The anatomy of empire. New York: Mason \& Lipscomb Publishers.

McDevitt, P. F. (2004). May the best man win: Sport, masculinity, and nationalism in Great Britain and the Empire, $1880-1935$. New York: Palgrave Macmillan.

McKay, J., Messner, M. A., \& Sabo, D. (Eds.). (2000). Masculinities, gender relations, and sport. Thousand Oaks, California: Sage Publications, Inc.

Merrill, D., \& Paterson, T. G. (Eds.). (2000). Major problems in American foreign relations. Volume I: To 1920 (5th ed.). "Theodore Roosevelt Preaches the Manly Virtues of Overseas Expansion, 1899”. Boston: Houghton Mifflin Company.

O'Connor, J. J. (1981, July 15). TV: Cecil Rhodes sits for an ironic portrait. The New York Times.

Perkins, B. (1968). The Great Rapprochement: England and the United States, 1895-1914. New York: Atheneum.

Putney, C. (2001). Muscular Christianity: Manhood and sports in Protestant America, 1880-1920. Cambridge, Massachusetts: Harvard University Press.

Quigley, C. (1981). The Anglo-American establishment: From Rhodes to Cliveden. San Pedro, California: GSG \& Associates Publishers.

Roberts, B. (1988). Cecil Rhodes: Flawed Colossus. New York: W. W. Norton \& Company.

Rhodes, C. (1902). The last will and testament of Cecil John Rhodes: With elucidatory notes to which are added some chapters describing the political and religious ideas of the testator. W.T. Stead, (Ed.). The Bodleian Library, Oxford.

Rohr, G. (1999). An African-American Rhodes scholar confronts the ghost of Cecil Rhodes. The Journal of Blacks in Higher Education, 23, 102-103. 
Roosevelt, T. (1913). Theodore Roosevelt: An autobiography. New York: The Macmillan Company.

Rotberg, R. I. (1988). The founder: Cecil Rhodes and the pursuit of power. New York: Oxford University Press.

Rotberg, R. I. (2014). Did cecil Rhodes really try to control the world? The Journal of Imperial and Commonwealth History, 42(3), 551-567.

Schaeper, T. J., \& Schaeper, K. (1998). Cowboys into gentlemen: Rhodes scholars. Oxford, and the creation of an American elite. New York: Berghahn Books.

Testi, A. (1995). The Gender of reform politics: Theodore Roosevelt and the culture of masculinity. The Journal of American History, 81(4), 1509-1533.

Verschoyle, F. (1900). Cecil Rhodes: His political life and speeches, 1881-1900. London: Chapman and Hall.

Watts, S. (2003). Rough Rider in the White House: Theodore Roosevelt and the politics of desire. Chicago: The University of Chicago Press.

Ziegler, P. (2008). Legacy: Cecil Rhodes, the Rhodes trust, and Rhodes scholarships. New Haven: Yale University Press.. 